\title{
RECENT STATE AND MECHANISMS OF INVASIONS OF EXOTIC DECAPODS IN UKRAINIAN RIVERS
}

\author{
M. O. Son ${ }^{1}$, R. A. Novitsky², V. G. Dyadichko' \\ ${ }^{1}$ Odessa Branch of O. O. Kovalevsky Institute of Biology of the Southern Seas NASU, \\ vul. Pushkinskaya, 37, Odessa, 65011 Ukraine \\ E-mail:michail.son@gmail.com,w_dyadichko@gmail.com \\ ${ }^{2}$ Oles Honchar Dnepropetrovsk National University, \\ Prospect Gagarina, 72, Dnepropetrovsk, 49050 Ukraine \\ E-mail: zoolog@ukr.net
}

Recent State and Mechanisms of Invasions of Exotic Decapods in Ukrainian Rivers. Son M. O., Novitsky R. A., Dyadichko V. G. - Lower reaches of largest Ukrainian rivers are zones of migrations for exotic euryhaline decapods. During 2000s new records of invasions of three euryhaline exotic decapods, Rhithropanopeus harrisii (Gould, 1841), Eriocheir sinensis Milne-Edwards, 1853 and Macrobrachium nipponense (De Haan, 1849), were made in the channels of Ukrainian rivers. Chinese mitten crab, E. sinensis, spread in the Danube Delta and reservoirs of the Dnieper River; Rh. harrisii - in the channels of the Danube, Dnieper, Southern Bug and small river Gruzskij Yelanchik in the Azov Sea Basin; M. nipponense that was introduced in the Kuchurgan Liman (cooler reservoir of the Moldavian Hydro-power Station ) - in the Dniester Delta. The migration zone of the established population can cover significant part of river watershed; it is necessary to take this fact into account at an estimation of biological invasion risk. Main problem in the investigation of exotic decapods in Ukrainian waters is absence of specialized methods used in the standard ecological monitoring. Among euryhaline exotic decapods, only $R h$. harrisii is sometimes sampled with the equipment used in the monitoring of macrozoobenthos. A few records of these species at the large extent of their supposed ways of migration are the result of gaps in the study of their distribution in Ukrainian inland waters. Realistic attitude toward this fact is very important for the estimation of invasions in the inland waters of this region.

Key words: invasive alien species, Decapoda, Rhithropanopeus harrissii, Eriocheir sinensis, Macrobrachium nipponense, Ukraine.

Современное состояние и механизмы инвазий экзотических декапод в украинские реки. Сон М. О., Новицкий Р. А., Дядичко В. Г. - Низовья крупнейших украинских рек являются зонами миграции экзотических эвригалинных декапод. В течение 2000-х гг. несколько случаев инвазий трёх эвригалинных экзотических декапод: Rhithropanopeus harrisii (Gould, 1841), Eriocheir sinensis (Milne-Edwards, 1853) и Macrobrachium nipponense (De Haan, 1849) были указаны для русел украинских рек. Китайский мохнаторукий краб, E. sinensis, распространяется в дельте Дуная и водохранилищах Днепра; Rh. harrisii - в русле Дуная, Днепра, Южного Буга и малой реки Грузский Еланчик в бассейне Азовского моря; M. nipponense, акклиматизированный в Кучурганском лимане (пруд-охладитель Молдавской ГРЭС) - в дельте Днестра. Зона миграции установившейся популяции может охватывать значительную часть речного бассейна, что необходимо учитывать в оценке риска биологических инвазий. Главная проблема в исследованиях экзотических декапод в водах Украины - отсутствие специализированных методов в стандартном экологическом мониторинге. Среди эвригалинных экзотических декапод только Rh. harrisii иногда оказывается пойманным с помощью орудий лова, используемых в мониторинге макрозообентоса Малочисленность известных находок этих видов при большом протяжении некоторых предполагаемых путей миграции - результат пробелов в изучении распространения таких видов во внутренних водах Украины. Реалистическое отношение к современному состоянию научных исследований очень важно для оценки инвазий во внутренние воды страны.

Ключе вы е с ло ва: инвазивные чужеродные виды, Decapoda, Rhithropanopeus harrissii, Eriocheir sinensis, Macrobrachium nipponense, Украина.

\section{Introduction}

Expansion of a number of invasive alien decapods has been reported in European waters during last decades (Holdich, Pöckl, 2007). In Ukraine, invasive decapod species were reported mainly from the marine and brackish coastal waters of the Azov-Black Sea coasts (Alexandrov et al., 2007). During 2000s new records of inva- 


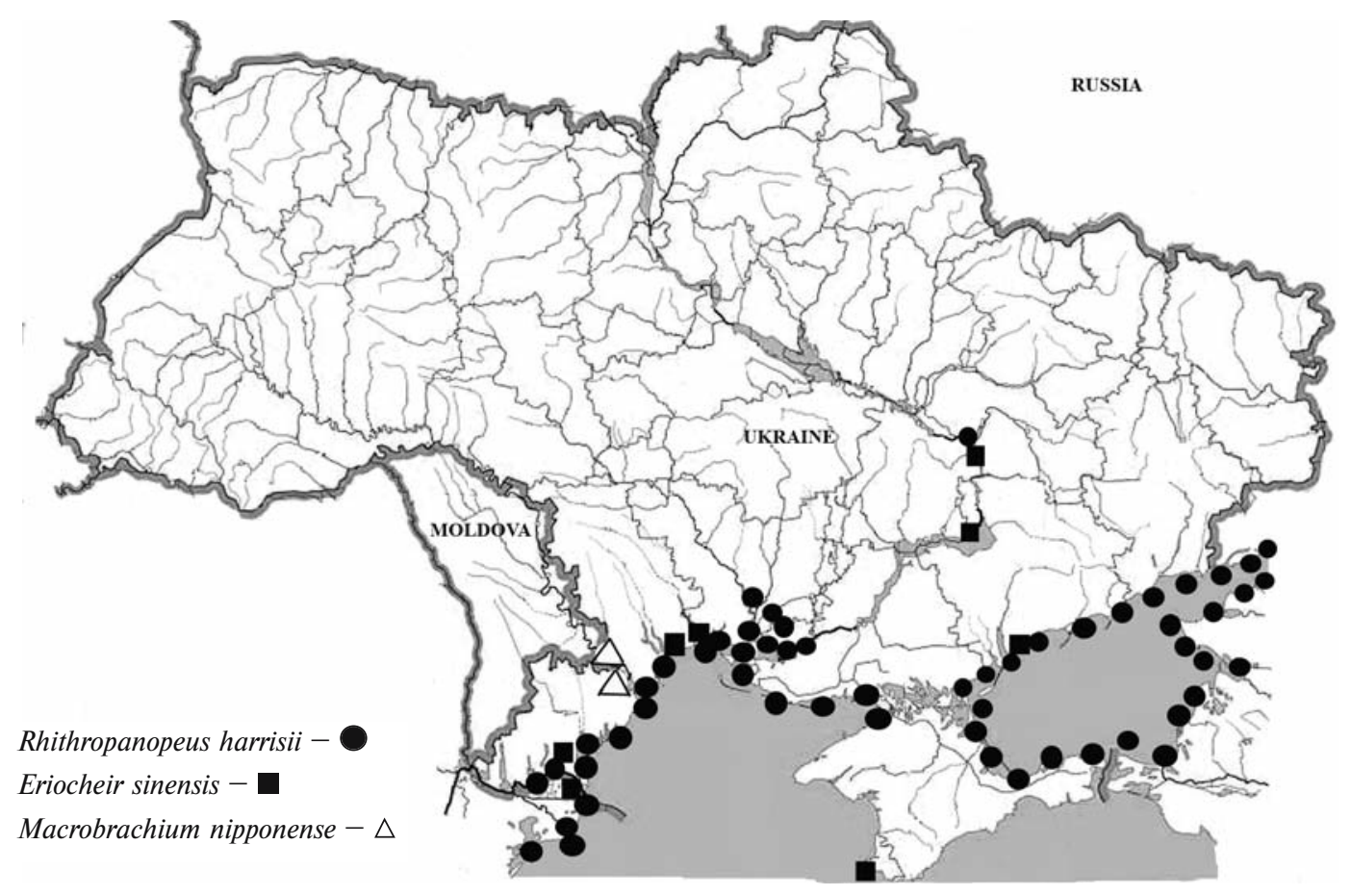

Fig. 1. Invasive ranges of eurihaline decapods in Ukraine.

Рис. 1. Находки эвригалинных декапод в Украине.

sions of three euryhaline exotic decapods, Rhithropanopeus harrisii (Gould, 1841), Eriocheir sinensis MilneEdwards, 1853 and Macrobrachium nipponense (De Haan, 1849), were made in the Ukrainian rivers (fig. 1). In this paper we report these occurrences with special attention to the most upstream records of the species.

\section{Material and methods}

Part of the sampled areas are the zones of regular investigations of aquatic invasions, which had been previously studied (Dniester Delta since 1999, Middle Dnieper since 2000, Danube River since 2002). In localities in the Southern Bug River, Ingul River, and Gruzskij Yelanchik River, Rh. harrisii was found du-ring the first field investigations.

Material. M. nipponense: 1 specimen, Dniestr Delta $\left(46^{\circ} 30^{\circ} 06.6 \mathrm{~N} ; 29^{\circ} 55^{\circ} 51.5\right.$ E), 05.07.2009 (Dyadichko); Rh. harrisii: 1 specimen, Dnieprovskoye Reservoir (48²4‘58.0 N; 35०06`41.0 E), 06.11.2009 (Novitsky); 5 specimens, Ingul River, Nikolayev Port (4659‘48.3 N; 3200`20.9 E), 03.07.2007 (Son); 3 specimens, Southern Bug River ( $46^{\circ} 58^{\circ} 56.5$ N; $31^{\circ} 58^{`} 11.1$ E), 03.07.2007 (Son); 4 specimens, Southern Bug River

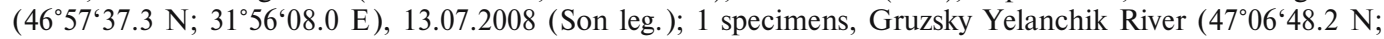
$38^{\circ} 03^{`} 49.2$ E), 09.08.2004 (Son); 2 specimens, Danube River, Izmail (40²0`19.8 N; 2848‘35.6 E), 08.06.2009 (Son); E. sinensis: 1 specimen, Dnieprovskoye Reservoir (4806‘51.0 N; 3503‘01.0 E), 20.10.2002 (Novitsky).

E. sinensis from the Dnieprovskoye Reservoir was found in fishnet (mesh size $40 \mathrm{~mm}$ ) at $10 \mathrm{~m} \mathrm{depth}$. $R h$. harrisii from the Dnieprovskoye Reservoir was sampled on stony bottom at $2 \mathrm{~m}$ depth with bottom fishnet (mesh size $14 \mathrm{~mm}$ ). Material from the Dnieper Basin was fixed in $4 \%$ formalin. It is deposited at the Oles Honchar Dnepropetrovsk National University (Department of Zoology and Ecology).

Other samples of Rh. harrisii were sampled with hand-net or by hands. The specimens were fixed in $70 \%$ ethanol. They are deposited in the collection of the Odessa Branch of O. O. Kovalevsky Institute of Biology of the Southern Seas (OB IBSS).

Freshwater prawn $M$. nipponense was sampled with specialized crayfish's trap with bait. It was fixed in $70 \%$ ethanol and deposited in the collection of the OBIBSS.

\section{Results and discussion}

Chinese mitten crab E. sinensis was registered in two Ukrainian estuaries in 1998. In June 1998, it was sampled in the Grigorjevskiy Liman, North-West Black Sea Region (area of Yuzhny Port) (Zaitsev, 1998), and in 08.05.1998, in the Molochnyj Liman near place of connection with the Sea of Azov (Murina, Antonovsky, 2001). In subsequent 
years, rapid spread of this species was reported in the Northern Black Sea region. It was found along the Black Sea coast between Bolshoj Fontan Cape (the city of Odessa) and the town of Ilichovsk in February 2000, in the Zhebrian Bay near the Danube Delta (Danube Biosphere Reserve) in November 2003 (Lukarzhevskaya, 2004), and in 31.03.2005, near the city of Sevastopol (according to communications with the local fishermen, it has appeared in this region several years before and has been found in marine bays and near the estuary of Chornaya River) (Lozovskij, 2005).

Shortly after first records of $E$. sinensis in the estuarine and coastal waters it was reported from the reservoirs of the Dnieper River. It was found in the Dnieprovskoye Reservoir (20.10.2002) and according to the data from Zaporozhje Regional Fishery Inspection in the Kakhovka Reservoir, near the town of Kakhovka (15.01.2003) (fig. 2).

In the Black sea waters, Harris mud crab Rh. harrisii was reported for the first time in the estuarine Dnieper-Bug Liman in 1939. Later it has spread to other freshened areas, and in 1948 has penetrated into the Sea of Azov (Makarov, 2004). Before our investigations, this species has been also reported from the Black Sea coastal lagoons and estuaries: Sasyk Lake, Alibej, Shagany, Sukhoj Liman, Khadzhibey Liman, and Tliligulskij Liman (Makarov, 2004). Among coastal reservoirs we also found it in estuarine Berezan Liman. Among large river systems its presence was reported only for branches of the Danube Delta, its inundated lakes and adjoining reservoirs (Lyashenko et al., 2005; Dzhurtubaev, 2010). We indicate the town of Izmail as the most upstream point of its distribution in Ukrainian Danube Basin.

In the Dnieper Basin, this species is widespread in the Dnieper-Bug Liman (Makarov 2004) and waters of the Kherson Commercial Seaport in the Dnieper Delta (Yury Kvach, personal communication). The most upward records of this species in the Dnieper Basin is the middle part of the Dnieprovskoye Reservoir near the Pridneprovskaya Thermal Power Station (fig. 3). In the Southern Bug Basin, we found this species in the channels of the Southern Bug River, and its tributary, Ingul River. In addition to the records in large rivers, the species also has been found in a small river, Gruzskij Yelanchik (Azov Sea Basin).

Giant prawns of the genus Macrobrachium are a key element of modern freshwater aquaculture. In the former USSR, experimental cultivation of M. nipponense and M. rosenbergii (De Man, 1879) was organized in natural and warm-water reservoirs before 1970s (Suprunovich, Makarov, 1990). In 1986, M. nipponense was introduced into the Kuchurgan Liman (cooler reservoir of the Moldavian Hydro-power Station), waterbody on the Transdnistrian stretch on the border between Ukraine and Moldova Republic (Makarov, 2004). M. rosenbergii has been cultivated in the closed reservoirs of the Crimean

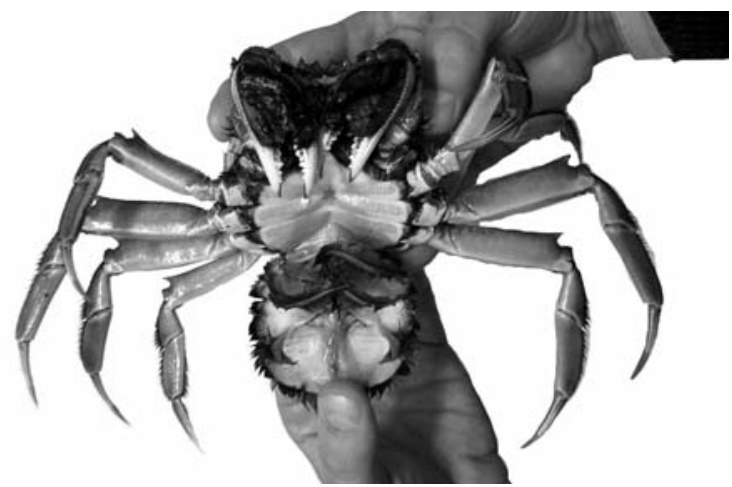

Fig. 2. Chinise mitten crab, Eriocheir sinensis, from the Dneprovskoye Reservoir (photograph by R. A. Novitsky). Рис. 2. Китайский мохнаторукий краб, Eriocheir sinensis, из Днепровского водохранилища (фото Р. А. Новицкого). 


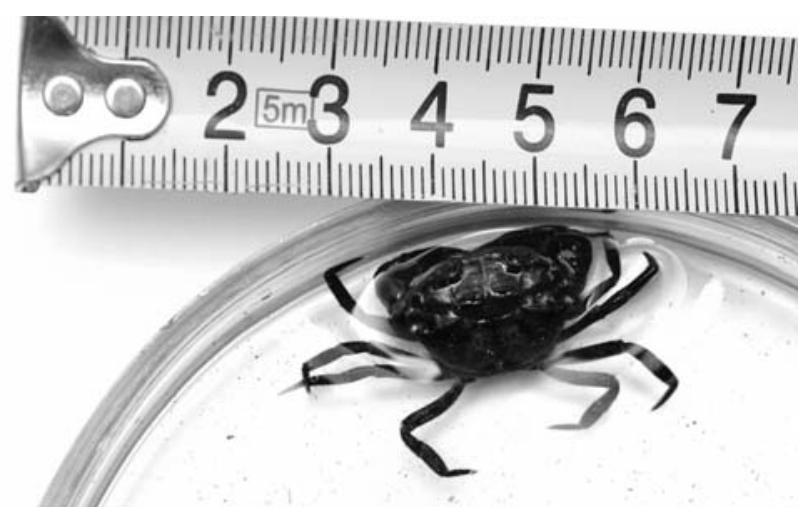

Fig. 3. Harris mud crab, Rhithropanopeus harrisii, from the Dneprovskoye Reservoir (photograph by R. A. Novitsky).

Рис. 3. Голландский краб, Rhithropanopeus harrisii, из Днепровского водохранилища (фото Р. А. Новицкого).

Peninsula, but no data about its possible escape from aquaculture or introduction to the natural Ukrainian ecosystems exist so far.

M. nipponense is a widespread Indo-Pacific species, occurring in estuarine and fresh waters (New et al., 2010). Before 2000s, it has not been reported from the Dniester Basin, except for warm-water zone of the Kuchurgan Liman. Reports from the local fishermen about a giant prawn in the Dniester Delta appeared since 2000s. Adult specimen of M. nipponense was recorded in the Dniester River while sampling with specialized crayfish trap with bait.

Thus, it is obvious that the lower reaches of the largest Ukrainian rivers are the zones of migrations for exotic euryhaline decapods. Possible pathways are shipping, local thermal pollution, and also man-made high mineralization. The zone of migration of the established population can cover significant reach of river watershed, which is necessary to take into account at an estimation of biological invasion risk. For example, for a migrating species which breeding occurs in an estuary, the upstream findings should automatically indicate the necessity to take this species into account in the risk estimation for all intermediate sites.

All three species of exotic euryhaline decapods recorded in Ukrainian rivers have different modes of migratory behaviour.

The Chinese mitten crab breeding in estuaries requires saltish water on larval stages, but it is capable of movements on large distances upstream rivers. In Europe, the length of such migrations reaches up to $700 \mathrm{~km}$ that is provided with speed of upstream migration as large as $1-1.5 \mathrm{~km}$ per day (Makarov, 2004). Thus, significant part of Ukrainian inland waterways is a zone of its potential spreading.

Euryhaline $R h$. harrisii do not migrate on significant distances during its life cycle. That is connected with a specific mechanism of zoean vertical migrations between layers of water moving in the different sides (Cronin, Forward, 1986). This mechanism retains larvae within the vicinity of the parental population. Probably, it provides success of adaptation to local conditions, in particular, by a choice of the most successful habitats. It was reported that Portuguese population has moved around $6 \mathrm{~km}$ upward in the Mondego River within a period of 10 years, completely disappearing from the previous sampling site (Projecto-Garcia, 2010). Earlier it was affirmed that the larvae of this species are less tolerant to low salinities than adults (as low as $4 \%$ ). However, recent discovery of breeding populations of $R h$. harrisii in Texas freshwater reservoirs showed the presence of gravid females, abundant juveniles, zoeae and egg production at salinities as low as $0.5 \%$ (Boyle et al., 2010). The fact of modern colonization of fresh-water reservoirs close to the native range is very interesting and shows that the importance of salinity as limiting fac- 
tor in spreading of this species is probably exaggerated at least for high-mineralised rivers. Laboratory experiments showed that vertical migration rhythms of the larvae were formed on embryonic stages and were connected with tidal rhythms of an estuary (Makarov, 2004). It is so for the microtidal Black and Azov Seas, where such migrations during time of windeffected surge phenomena is improbable.

Thus, taking into account weak mobility of these crabs in comparison with large migrating species, such as Chinese mitten crab E. sinensis or blue crab C. sapidus, larval drift is the main factor preventing upstream spread of $R h$. harrisii in the Ponto-Caspian rivers.

Evolution of the prawn genus Macrobrachium towards «freshwaterization» has resulted in occurrence of several life cycle types and related larval developmental patterns. The type, which includes $M$. nipponense, is represented by species which undertake migration to estuaries during the breeding season, since their larvae essentially require higher salinity for successful metamorphosis (Jalihal et al., 1993). However, M. nipponense very quickly adapts to fresh water in comparison to the closely related species (New et al., 2010). Therefore, migrations of $M$. nipponense in conditions of the Dniester Basin are limited not by salinity, but by temperature - optimal water temperature for this species is $25-28^{\circ} \mathrm{C}$ (Suprunovich, Makarov, 1990). The estuarine Kuchurgan Liman, being a cooler pond, plays a role of temperature refugium for this species in the Dniestr Basin and the potential zone of migration, which is probably limited to those distances that species can pass in a warm season. Such zones of migration for M. nipponense are known in the Volga River (Yakovleva, Yakovlev, 2010). Now it is not clear whether these prawns return to the Kuchurgan Liman or their populations are incapable of reproduction.

Main problem in investigation of exotic decapods in Ukrainian waters is absence of specialized methods for the standard ecological monitoring. Among euryhaline exotic decapods, only $R h$. harrisii is sometimes sampled with equipment officially used in macrozoobenthic monitoring. In all publications, dedicated both to E. sinensis and Callinectes sapidus Rathbun, 1896, where the source of the materials was indicated, data are based on samples received from fishermen and amateur divers (including scientists, who catch these specimens as hobby, but not during official monitoring expeditions) or samples from ichthyological studies (Bulgurkov, 1968; Zaitsev, 1998; Murina, Antonovsky, 2001; Novitsky, 2003; Lozovskij, 2005; Diripasko et al., 2009). All Black Sea specimens of potential invaders to estuaries and lower reaches of Ukrainian rivers: palemonid prawns, Palaemon longirostris H. Milne-Edwards, 1837, and P. macrodactylus Rathbun, 1902, and Says mud crab, Dyspanopeus sayi (S. I. Smith, 1869), were also captured by SCUBA divers or diver-operated push-nets (Sezgin et al., 2007; Micu, Niță, 2009; Micu et al., 2010).

A few records of these species at large extent of their supposed migration ranges is a result of gaps in studies of the distribution of such species in Ukrainian inland waters. Realistic attitude towards this fact is very important for the estimation of invasions in the inland waters of this region.

Surprisingly, none of the numerous exotic freshwater crayfishes, which invaded European waters (Holdich, Pöckl, 2007) or are available as ornamental aquarium species (Chucholl, 2012 - in press), have been reported from Ukraine. At least Orconectes limosus (Rafinesque, 1817) could already attain the territory of Ukraine both from the Romanian Lower Danube and the Vistula Basin (from Poland and Belarus). Also we estimate a high risk of introduction of different Procambarus species by aquarium hobbyists.

\section{References}

Alexandrov B. G., Boltachev A. R., Kharchenko T. V. et al. Trends of aquatic alien species invasion in Ukraine // Aquatic invasions. - 2007. - 2, N 3. - P. 215-242.

Boyle T., Keith D., Pfau R. Occurrence, reproduction, and population genetics of the estuarine mud crab, Rhithropanopeus harrisii (Gould, 1841) (Decapoda, Panopidae) in Texas freshwater reservoirs // Crustaceana. - 2010. - 83, N 4. - P. 493-505. 
Bulgurkov K. I. Callinectes sapidus Rathbun (Crustacea - Decapoda) in the Black Sea // Izvestiya NII Rybno Stopanstvo i Oceanografiya. - 1968. - 9. - P. 97-99. - Russian : Булгурков К. И. Callinectes sapidus Rathbun (Crustacea - Decapoda) в Чёрном море.

Cronin T. W., Forward R. B. Vertical migration cycles of crab larvae and their role in larval dispersal // Bulletin Marine Science. - 1986. - 39. - P. 192-201.

Diripasko O. A., Izergin L. V., Koshkalda A. I. The first finds of blue crab, Callinectes sapidus (Portunidae, Decapoda), in the Sea of Azov // Vestnik zoologii. - 2009. - 43, N 6. - P. 529-532. - Russian Дирипаско О. А., Изергин Л. В., Кошкалда А. И. Первые находки голубого краба, Callinectes sapidus (Portunidae, Decapoda), в Азовском море.

Dzhurtubaev M. M., Dzhurtubaev Yu. M., Zamorova M. A. Zoobentos in Danubian Lakes // Naukovi zapiski Ternopilskogo natsionalnogo pedagogichnogo universitetu. Ser. Biologiya. - 2010. - 2. - P. 163-166. Russian : Джуртубаев М. М., Джуртубаев Ю. М., Заморова М. А. Зообентос придунайских озер.

Holdich D. M., Pöckl M. Invasive crustaceans in European inland waters Holdich. Invasive crustaceans in European inland water // Biological invaders in inland waters: profiles, distribution and threats. - The Netherlands : Springer, 2007. - P. 29-75.

Jalihal D. R. Sankolli K. N. Shenoy Sh. Evolution of larval developmental patterns and the process of freshwaterization in the prawn genus Macrobrachium Bate, 1868 (Decapoda, Palaemonidae) // Crustaceana. 1993. - 65, N 3. - P. 365-376.

Lozovsky $V$. L. First record of the Chinese crab Eriocheir sinensis, exotic alien in the Black sea Basin, at a coast of Sevastopol // Morskyj Ecologichnyj Zhurnal. - 2005. - 4, N 2. - P. 58. - Russian : Лозовский В. Л. Первая находка у берегов Севастополя китайского краба Eriocheir sinensis - экзотического вселенца в бассейне Черного моря.

Lukarzhevskaya S. V. Penetration of Chinese mitten crab (Eriocheir sinensis H. Milne Edwards, 1854) in the estuarine areas of the rivers Dnister and Danube // Integrated Management of Natural Resources in the Transboundary Dniester River Basin: International conference. - Chisinau, 16-17 September 2004. Chisinau : Eco-TIRAS, 2004. - P. 197-199. - Russian : Лукаржевская С. В. Проникновение китайского мохнатопалого краба (Eriocheir sinensis Milne-Edwards, 1854) в устьевые зоны рек Днестр и Дунай.

Lyashenko A. V., Sinitsina O. O., Voloshkevich Yu. V. Bottom invertebrates as alien newcomers in water bodies of the lower reaches of the Danube // Hydrobiological Journal. - 2005. - 41, N 6. - P. 56-65.

Makarov Yu. N. Fauna of Ukraine. Decapoda. - Kyiv : Naukova Dumka, 2004. - Vol. 26. - 429 p. Ukrainian : Макаров Ю. Н. Фауна України. Decapoda.

Micu D., Niță V. First record of the Asian prawn Palaemon macrodactylus Rathbun, 1902 (Caridea: Palaemonoidea: Palaemonidae) from the Black Sea // Aquatic Invasions. - 2009. - 4, N 4. P. 597-602.

Micu D, Nița V., Todorova V. First record of Say's mud crab Dyspanopeus sayi (Brachyura: Xanthoidea: Panopeidae) from the Black Sea // Marine Biodiversity Records. - 2010. - 3, N 36. - P. 1-6.

Murina $V$. V., Antonovsky A. G. Cninese crab, Eriocheir sinensis, is an invader into the Azov Sea Basin // Ekologiia Moria. - 2001. - 55. - P. 37-39. - Russian : Мурина В. В., Антоновский А. Г. Китайский краб Eriocheir sinensis - вселенец в бассейн Азовского моря.

Novitsky R. A. About the finds of the Chinese mitten crab Eriocheir sinensis (Decapoda) in the Dnepr Reservoires // Vestnik zoologii. - 2003. - 37, N 3. - P. 30. - Russian : Новицкий Р. А. О находках китайского мохнаторукого краба Eriocheir sinensis (Decapoda) в днепровских водохранилищах.

Projecto-Garcia J., Cabral H., Schubart Ch. D. High regional differentiation in a North American crab species throughout its native range and invaded European waters: a phylogeographic analysis // Biological Invasions. $-2010 .-12, \mathrm{~N} 1 .-$ P. 253-263.

Sezgin M., Aydemir E., Ateş A. S. et al. On the presence of the non-native estuarine shrimp, Palaemon longirostris Milne-Edwards, 1837 (Decapoda, Caridea), in the Black Sea // Aquatic Invasions. — 2007. 2, N 4. - P. 464-465.

Suprunovich A. V., Makarov Yu. N. Cultivaded invertebrates. Food invertebrates: mussels, oysters, scallops, cryfishes, shrimps. - Kyiv : Naukova dumka, 1990. - 264 p. - Russian : Супрунович А. В., Макаров Ю. $H$. Культивируемые беспозвоночные. Пищевые беспозвоночные: мидии, устрицы, гребешки, раки, креветки.

Yakovleva A. V., Yakovlev V. A. Recent fauna and quantitative parameters of invasive invertebrates in zoobenthos of the upper reaches of Kuybyshev reservoir // Rossiiskij Zhurnal Biologicheskikh Invasij. 2010. - 2. - P. 97-111. - Russian : Яковлева А. В., Яковлев В. А. Современная фауна и количественные показатели инвазионных беспозвоночных в зообентосе верхних плесов Куйбышевского водохранилища.

Zaitsev Yu. Marine hydrobiological investigations of National Academy of Sciences of Ukraine in 1990s of XX century // Hydrobiologcheskyi Zhurnal. - 1998. - 34, N 6. - P. 3-21. - Russian : Зайцев Ю. П. Морские гидробиологические исследования Национальной академии наук Украины в течение 90-х годов $\mathrm{XX}$ столетия.

Received 11 September 2012

Accepted 21 November 2012 